\title{
Phonological Awareness and Working Memory in Arabic-Speaking Egyptian Preschool Children at Risk for Dyslexia
}

\author{
Amal M. Zayed ${ }^{1}$, Alysia D. Roehrig ${ }^{2}$, M. Caridad Arrastia-Lloyd ${ }^{2} \&$ Nasra M. Gilgil ${ }^{1}$ \\ ${ }^{1}$ College of Education, Kafrelsheikh University, Egypt \\ ${ }^{2}$ College of Education, Florida State University, USA
}

Correspondence: Amal M. Zayed, College of Education, Kafrelsheikh University, Egypt. E-mail:amalmzayed@yahoo.com

Received: November 8, 2012

doi:10.5539/ijps.v5n1p139

\author{
Accepted: February 19, $2013 \quad$ Online Published: February 21, 2013 \\ URL: http://dx.doi.org/10.5539/ijps.v5n1p139
}

\begin{abstract}
This purpose of this study was to examine the relationship between phonological awareness, verbal working memory, and risk for dyslexia in Arabic language in preschool children. The participants of this study were preschool children between the ages of five and six, who represented two groups: (20) children at risk for dyslexia and (20) children normal without any risk for dyslexia. These children were randomly selected from a larger sample of 425 preschool children in Egypt. Phonological awareness and verbal working memory tasks were used to compare children's abilities. The findings indicate that there is a strong relationship between phonological awareness and working memory. In addition, phonological awareness and working memory may have an effect on children's phonological sensitivity and reading skills.
\end{abstract}

Keywords: phonological awareness, working memory, dyslexia

\section{Introduction}

In this study the relationship between phonological awareness (PA) and working memory (WM) in Arabic-speaking preschool children in Egypt who are at risk for dyslexia, and their counterparts, was investigated. Although this relationship is well understood in the context of English-language speakers (Bruck, 1992; Bruck \& Treiman, 1990; Swan \& Goswami, 1997), few studies in the Arabic-language literature have examined these variables (Ashour, 2011; Khalil \& Dowah, 2007; Othman, 2009; Zayed, 2011) let alone the relationship between both PA and WM in children at risk for dyslexia. Poor PA, however, has been found to be a strong indicator of dyslexia among Arabic-speakers (Al Mannai \& Everatt, 2005; Ashour, 2011; Othman, 2009) and subsequent interventions have been successful in remediating the reading disorder (e.g., Ashour, 2011). To date, there are insufficient empirical studies in the Arabic-language literature to describe the problem of dyslexia in Egypt (Elbeheri, 2004, 2007; Elbeheri, Everatt, Reid, \& Al Mannai, 2006; Gilgil, 1995).

Studies considering the effect of WM on dyslexia have also found that WM has a strong influence on the ability to read and spell in Arabic (Khalil \& Dowah, 2007; Zayed, 2011). However, these studies did not investigate the theoretical relationship between WM and PA in combination for children in this population. The authors, therefore, have considered both PA and WM in this study to identify their role in dyslexia. The goal was to contribute to the Arabic-language reading research by examining the relationship of the aforementioned variables. The research questions were as follows: what is the relationship between PA and WM for Arabic-speaking preschoolers at risk for dyslexia compared to others? Do those at risk demonstrate poorer skills in terms of PA and WM?

\section{Literature Review}

Dyslexia is commonly understood to involve spelling and reading difficulties that are "discrepant with intelligence and educational opportunities" (de Bree, 2007, p. 6). It is typically considered a language-based disorder (e.g., Catts, 1989; de Bree, 2007; Kamhi \& Catts, 1986; Vellutino, 1979) that is characterized by a number of deficits. Phonological processing, in particular impairments related to phonological awareness (PA), is considered one of the core deficits characterizing dyslexia (Carroll \& Snowling, 2004; Joanisse, Manis, Keating, \& Seidenberg, 2000). PA refers to the explicit knowledge of the units that make up spoken words including syllables, onset and rime units and individual phonemes (Rvachew, Ohberg, Grawburg, \& Heyding, 2003) and 
has been defined as the awareness of and access to the sound structure of one's oral language (Wagner \& Torgesen, 1987). PA involves the awareness of the most basic speech units of a language, phonemes, as well as the larger units, such as rimes and syllables (Bird, Bishop, \& Freeman, 1995; Rvachew et al., 2003; Stackhouse, Wells, Pascoe, \& Rees, 2002).

Although dyslexia is "generally acknowledged to involve difficulties in phonological processing, the links between reading difficulties and speech difficulties remain unclear" (Carroll \& Snowling, 2004, p. 631). Deficits in phonological processing may result in "an inability to understand the sound structure of language" (Pneuman, 2009 , p. 7) making reading difficult. One of the variety of factors that contributes to the deficits associated with dyslexia is impaired WM (Scheepers, 2009). WM refers to the system that is responsible for temporarily storing and manipulating information. It functions as a mental workspace that can be flexibly used to support everyday cognitive activities that require processing and storage (Alloway et al., 2005). Although the roles of PA and WM deficits have been studied in English-speakers, reading research has not investigated the relationship of these variables among Arabic-speaking dyslexics. In order to understand reading development for Arabic speakers, reading difficulties should be examined among both dyslexic and non-dyslexic preschoolers.

\subsection{PA and Dyslexia}

PA is one of the phonological processing skills known to be important in early decoding (Bowey, 2001; Snowling, Chiat, \& Hulme, 1991). Thus, PA plays a great role in the acquisition of literacy. Many findings show that it is a single ability that manifests itself in a variety of skills that emerge in a sequence and may predict later reading ability (Anthony \& Francis, 2005). The importance of PA, as foundational for the development of reading skills, has been investigated in many studies (e.g., Anthony \& Francis, 2005; Ehri, 1991, 1994; Morais, Bertelsen, Cary, \& Alegria, 1987; Share, Jorm, MacLean, \& Matthews, 1984; Snow, Burns, \& Griffin, 1998; Stanovich, 1994), and PA has been found to be a strong predictor of children's reading ability (Ehri et al., 2001; Snow, Burns, \& Griffin, 1999; Storch \& Whitehurst, 2002). Moreover, evidence indicates that many children who have reading difficulties also have impairments in PA and information processing ability (Leather \& Henry, 1994; Oakhill \& Kyle, 2000; Share \& Stanovich, 1995; Wagner et al., 1997).

It is widely accepted that learning to read depends on PA and that children who have phonological difficulties may be at risk of reading problems (Snowling, 2001). In other words, problems in performing and applying PA capabilities are at the heart of most children's reading difficulties, regardless of other types of language and cognitive difficulties (Phillips, Clancy-Menchetti, \& Lonigan, 2008). Additional studies (e.g., Ashour, 2011; Bradley \& Bryant, 1983; Bruck, 1992, 1993; Fawcett \& Nicholson, 1995; Fletcher et al., 1994; Fox \& Routh, 1980; Lindamood, Bell, \& Lindamood, 1992; Lyon, 1995) have shown the significance of PA in the assessment and remediation of the individuals who have difficulty in reading (Ehri et al., 2001).

In particular, studies have shown that PA is a good predictor of reading performance in the first two years of schooling and also in later years even after controlling for possible confounding variables (Kirby, Parrila, \& Pfeiffer, 2003; Manis, Doi, \& Bhadha, 2000; Muter \& Snowling, 1998; Wagner et al., 1997). Many children start kindergarten with well-developed PA, some seem to develop these skills easily within a stimulating classroom environment, and others need more instruction that explicitly focuses on PA. Thus, early assessment and intervention is a necessity and may make a real difference to students with limited levels of PA (Trehearne, 2003). Nevertheless, PA impairments appear to be a persistent feature of dyslexia (Birch \& Chase, 2004; Pennington, Van Orden, Smith, Green, \& Haith, 1990; Wilson \& Lesaux, 2001).

Several lines of research have shown that PA deficits are causally related to reading difficulties. First, PA has been demonstrated to be a good predictor of reading ability (Kirby et al., 2003; Manis et al., 2000; Muter \& Snowling, 1998; Wagner et al., 1997). Second, studies with younger children and older dyslexics, who have been carefully matched on a measure of reading skill, indicated that dyslexics performed poorer on measures of PA (e.g., Kirby et al., 2003). Finally, remediation studies with children at risk for dyslexia showed that by improving PA there was a substantial improvement in reading ability in English-speaking populations (e.g., Ball \& Blachman, 1991; Blachman et al., 2004; Lovett, Steinbach, \& Frijters, 2000; Nicolson, Fawcett, Moss, Nicolson, \& Reason, 1999). However, English-speaking children who have dyslexia also been shown to have difficulties related to other language tasks in addition to reading and spelling (see Bishop, 2002, for a review; Rispens, 2004; Seidenberg \& McClelland, 1989; Snowling, 1981).

\subsection{Working Memory}

In general, it is widely accepted that dyslexic children have problems in WM (Jorm, 1983; Miles, 1983). WM, the information-processing system essential to learning and achievement in both school and work settings, consists of several components that work together to enable the active processing and preservation of 
information in memory (Baddeley, 2000; Gazzaniga, Ivry, \& Mangun, 2002). It has a significant effect on written communication and verbal skills, as well as, on organizing, planning and adjustment to any changes in the environment (McLoughlin, Leather, \& Stringer, 2002). Individuals with dyslexia have been found to have poor verbal WM. That is dyslexics take a long time to process information, especially when reading because they have to connect letter patterns with associated sounds (Alloway et al., 2005; Beneventi, Tønnessen, Ersland, \& Hugdahl, 2010; Gathercole \& Baddeley, 1993; Jeffries \& Everatt, 2004; McLoughlin et al., 2002; Nicolson, Fawcett, \& Baddeley, 1992).

Baddeley's (1986) three-component model of working memory consists of the visuo-spatial sketch pad in which one stores information temporarily and the phonological loop that in turn feeds information about letter sounds to the central executive component during reading. The central executive component controls the regulation of cognitions. The visuo-spatial sketch pad is the storage component of working memory where readers hold and are able to manipulate information (Baddeley, 1986). The phonological loop comprises an "articulatory rehearsal process" that is "analogous to subvocal speech" and "a phonological store" that can retain traces of memory momentarily before such cognitions fade away (Baddeley, 2003, p. 830). According to Baddeley, Gathercole, and Papagno (1998), the phonological loop is "specialized for the retention of verbal information over short periods of time" (p. 158) and consists of both a storage of sounds and a component enabling the retrieval and the articulation of such sounds. These two parts of Baddeley's (1986) model of working memory, the phonological loop and the visuo-spatial sketch pad, feed into the central executive system as both the storage and processing components of working memory.

Individuals who have dyslexia may also have specific problems with the phonological component in WM (Jeffries \& Everatt, 2003, 2004). They are not efficient enough to translate visual information (letters) into a phonological form (sounds), which may inhibit their ability to learn new words during reading. Phonological repetition is also challenging for dyslexics as they have problems retaining phonological information using rehearsal or repetition (Jeffries \& Everatt, 2004; Nation, Adams, Bowyer-Crane, \& Snowling, 1999; Smith-Spark $\&$ Fisk, 2007). Attaching appropriate verbal labels to pictures and remembering lists are also difficult cognitive tasks for dyslexics (de Jong, 1998; Jeffries \& Everatt, 2004).

\subsection{The Current Study}

Given the limited research on PA and WM and their relationship with dyslexia for Arabic-speakers, the goal of this study was to examine the relationship of the aforementioned variables in a sample of Arabic-speaking preschoolers. The research questions were as follows: what is the relationship between PA and WM for Arabic-speaking preschoolers at risk for with dyslexia compared to others? Do those at risk demonstrate poorer skills in terms of PA and WM?

\section{Method}

\subsection{Participants}

Forty students participated in this study: 20 children at risk for dyslexia (including 9 girls and 11 boys) and 20 children without risk for dyslexia as a comparison group (including 11 girls and 9 boys). Participants had a mean chronological age of 5.56 years $(S D=0.27)$. These children were randomly selected from the 425 children attending the seven local nursery schools in Kafr-Elsheikh, a town in northern Egypt. All nursery schools were attached to associated primary schools. All participants were native Arabic speakers without cognitive or neurological impairments. All children were screened with a battery of tests administered in Arabic including the DEST-2 in Arabic (Gilgil \& Agag, 2011), the Wechsler Intelligence Scales for Children (WISC-III; Wechsler, 1997), a PA test (AbdElgawaad, 2005) that has been validated and tested for reliability, and the Working Memory Test Battery for Children (WMTB-C; Pickering \& Gathercole, 2001). The children were individually tested in the school library during school time.

\subsection{Measures and Procedures}

\subsubsection{DEST-2}

The authors used a version of the Dyslexia Early Screening Test ( $2^{\text {nd }}$ edition, Nicolson \& Fawcett, 2004) that was translated into the Arabic language by Gilgil and Agag (2011). The DEST-2 battery, which is meant for ages 4:6 through 6:5, consists of 12 subtests (Rapid naming, Bead threading, Phonological discrimination, Postural stability, Rhyme/Alliteration, Forward digit span, Digit naming, Letter naming, Sound order, Shape copying, Corsi frog, and Vocabulary) that took a total of approximately 30 minute to be administered to each child. Following the guidelines for administration and scoring, children were identified for the at-risk of dyslexia group if their final composite score was between 1 and 10. Children identified as not at risk for the comparison group 
scored 76 or higher.

\subsubsection{PA}

The Phonological Awareness Test (AbdElgawaad, 2005) was used to assess children's PA. This test consists of four tasks: the rhyme detection task (11 items), syllable blending (13 items), phoneme isolation (12 items), and phoneme blending (12 items). The examiners presented four pictures to each child, named each picture, and then asked each child to identify (point to or say) the picture that begins with the sound produced orally by the examiners. During each assessment each child was asked to select the picture with the corresponding rhyme pattern, syllable, and phoneme. The examiner calculated the total number of initial sounds produced correctly in a minute.

\subsubsection{WM}

The authors used the Working Memory Test Battery for Children (WMTB-C; Pickering \& Gathercole, 2001) to measure the three components of WM from Baddeley's (1986) model. All three tasks from the battery were given. Each child was asked to recall a series of digits in the reverse order in the backwards digit recall test (14 items, phonological loop) and to count the number of dots in an array and then recall the tallies of dots in the counting recall test (17 items, visuo-spatial sketch pad). Each child was read a series of short sentences and was asked to produce the appropriate word to complete each sentence in the listening recall task ( 28 items; central executive).

\subsection{Data Analysis}

Using SPSS 20 (2011), Pearson correlations were calculated to examine the relationship between the PA and WM measures. To compare the performance of the two groups on the aforementioned PA and WM measures, analyses of variance (ANOVAs) were conducted.

\section{Results}

Means, standard deviations, and ranges were calculated for the at-risk group and their counterparts (see Table 1). Based on previous evidence on the developmental sequence of PA (rhyme, syllable, and phoneme) it was predicted that the comparison group would score higher on the rhyme detection, syllable blending, phoneme isolation, and phoneme blending tasks, as well as in WM tasks (backward digit recall, counting recall, and listening recall). Overall, all participants completed about half of the PA tasks correctly $(M=5.45-5.80, S D$ $=.36-.53)$. In terms of WM, at-risk participants performed poorly on all three tasks $(M=4.4-8.88, S D=.297$ $-.627)$.

Table 1. Descriptive statistics of phonological awareness and working memory tasks $(n=40)$

\begin{tabular}{lllll}
\hline & & \multicolumn{3}{c}{ Mean $(S D)$} \\
\cline { 3 - 5 } Measure & Range & All & At-Risk & Not At-Risk \\
\hline Phonological Awareness & & & & \\
Rhyme Detection Task & $1-10$ & $5.45(2.89)$ & $2.85(1.09)$ & $8.05(1.32)$ \\
Syllable Blending Task & $1-10$ & $5.56(3.04)$ & $2.65(1.14)$ & $8.25(1.07)$ \\
Phoneme Isolation Task & $1-11$ & $5.80(3.38)$ & $2.60(.99)$ & $9(.92)$ \\
Phoneme Blending Task & $2-9$ & $5.45(2.30)$ & $3.55(1.23)$ & $7.35(1.31)$ \\
Working Memory & & & & \\
Backward Digit Recall Task & $2-9$ & $4.40(1.88)$ & $2.90(.91)$ & $5.90(1.29)$ \\
Counting Recall Task & $2-12$ & $5.95(3.01)$ & $3.60(1.31)$ & $8.30(2.30)$ \\
Listening Recall Task & $3-20$ & $8.88(3.96)$ & $5.90(1.59)$ & $11.85(3.33)$ \\
\hline
\end{tabular}

In order to determine relationships between the variables, Pearson correlations for the subtests were calculated. Rhyme, syllable, and phoneme task scores were each significantly, positively correlated with the three WM tasks (see Table 2). 
Table 2. Correlations between phonological awareness and working memory tasks $(n=40)$

\begin{tabular}{lllll}
\hline Measures & Backward Digit Recall Task & $\begin{array}{l}\text { Counting } \\
\text { Task }\end{array}$ & $\begin{array}{c}\text { Recall } \\
\text { Listening } \\
\text { Task }\end{array}$ & Recall \\
\hline Rhyme Detection Task & $.76^{* *}$ & $.68^{* *}$ & $.712^{* *}$ \\
Syllable Blending Task & $.77^{* *}$ & $.75^{* *}$ & $.73^{* *}$ \\
Phoneme Isolation Task & $.77^{* *}$ & $.76^{* *}$ & $.73^{* *}$ \\
Phoneme Blending Task & $.80^{* *}$ & $.75^{* *}$ & $.65^{* *}$ \\
\hline
\end{tabular}

Note. ${ }^{* *}$ Correlation is significant at the 0.01 level (2-tailed)

A series of one-way ANOVAs was conducted to detect differences between the group at risk for dyslexia and their counterparts for each variable. The one-way ANOVAs revealed that the at-risk group did score lower on all seven tasks: rhyme detection, $F(1,38)=185.139$; syllable blending, $F(1,38)=257.139$; phoneme isolation, $F(1,38)=447.264$; backward digit recall, $F(1,38)=89.223$; counting recall, $F(1,38)=71.849$; and listening recall, $F(1,38)=52.073$, respectively. These differences were significant at the $p<.001$ level, even after adjusting the alpha level using the Bonferroni correction $(\alpha=.05 / 7=.007)$, confirming that the difference between groups was greater than the difference within groups (Cabin \& Mitchell, 2000). However, the variance of two of the WM measures, counting recall and listening recall, did not pass the Levene's test of homogeneity of variances. This is an indication of possible systematic bias in the sample data, but ANOVA is very robust to the violation of such assumption (Eisenhart, 1947).

\section{Discussion}

The main aim of this research was to examine the relationship between PA, WM, and risk for dyslexia in Arabic-speaking preschool children. Based on previous research, it was anticipated that children at risk for dyslexia would demonstrate deficiencies in phonological skills and working memory. The results confirm that the difference between groups was greater than the difference within groups, such that the Arabic preschoolers at risk for dyslexia demonstrated significant deficits in both PA and WM as compared to those not at risk for dyslexia.

The findings in Arabic-speaking children are consistent with those in English-speaking samples: children with dyslexia suffer impairments in both phonological skills and in WM performance (Nicolson et al., 1992). These findings suggest that when completing PA tasks, the WM's central executive may be involved in the encoding and storage of phonemes is involved in the (Hecht, Burgess, Torgesen, Wagner, \& Rashotte, 2001). They also suggest that a deficit in PA may be magnified by a deficit in verbal WM. If articulatory processing based on internal language is weak, short term memory traces are more difficult to refresh (Baddeley, 1993). This problem causes many symptoms as measured in outcomes, such as non-word repetition, PA, verbal memory, phonological learning of new verbal information, rapid naming, word retrieval, etc. (de Bree, 2007). These problems in turn lead to slow literacy development, poor generalization of word reading skills to non-word reading, and poor spelling development (Snowling 2001).

Swanson, Ashbaker, and Lee (1996) argued that when children with reading difficulties perform tasks with high processing demands, they tend to recall less verbal and visual-spatial information compared to their typically developing peers. In addition, the results of other studies (e.g., de Jong, 1998; Swanson, 2003; Swanson \& Ashbaker, 2000) also suggest that executive functioning difficulties may also be associated with the poor performance of WM and play a crucial role beyond the readers' deficits in phonological processing. Therefore, the central executive and the phonological loop may be important to typical or atypical reading development (Baddeley, 1992), which is consistent with the findings of the current study.

It is widely accepted that WM deficits are one of the most important factors underlying the phonological deficiencies in children with dyslexia. Think about the early problems of phonemic separation and the lack of awareness of rhyming that are usually related to reading deficits. It is very important for a word to be segmented into phonemes in order for a child to hold it temporarily in WM until it can be analyzed. If an individual cannot hold an unfamiliar word in one's short-term memory long enough to repeat it, segmenting the word poses an immediate challenge (Nicolson et al., 1992).

Scholars have demonstrated that in terms of cognitive capabilities, children with reading difficulties, particularly those with dyslexia, show impairments in a multitude of WM tasks (Alloway et al., 2005; Brunswick, McCrory, 
Price, Frith, \& Frith, 1999; Hansen \& Bowey, 1994; McDougall \& Donohoe, 2002; Palmer, 2000; Pennington et al., 2001; Plaza, Cohen, \& Chevrie-Mulleret, 2002; Roodenrys \& Stokes, 2001; Smith-Spark \& Fisk, 2007; Smith-Spark, Fisk, Fawcett, \& Nicholson, 2003; Snowling, 2008; Stanovich, Siegel, \& Gottardo, 1997; Swanson, 1994). These difficulties influence reading acquisition, reading ability, text comprehension and classroom functioning (Alloway \& Gathercole, 2006). According to Bradley and Bryant (1983), children diagnosed with dyslexia are not ready to read, in terms of PA, at the typical age of six years old. Early identification of dyslexia followed by targeted instruction providing intensive, well-designed scaffolds for phonological skills and other crucial literary skills may be imperative (Nicolson et al., 1992). For example, training for preschoolers at risk for reading disabilities can promote normal reading achievement (Bradley, 1988); however, it is unclear how well the phonological deficits are remediated.

Dialogic reading interventions have been found to improve PA skills among at-risk, Egyptian, kindergarten children (Elmonayer, 2012), but many areas of phonology have not been assessed in Arabic-speaking children at risk for dyslexia. The results of the present study are suggestive of very strong relations among PA, WM, and dyslexia; however, the directionality of the relationship is not illustrated by the correlational and cross-sectional analyses conducted in this study. Experimental studies need to be conducted in this population to establish such a causal conclusion. Thus, the authors recommend that future research be conducted to test the effectiveness of combining training of PA skills with WM skills for Arabic-speaking preschool children at risk for dyslexia.

\section{Conclusion}

In sum, the current findings indicate that PA plays a crucial role in the literacy development of Arabic-speaking preschoolers, as it does for English-speaking preschoolers (Anthony \& Francis, 2005). Moreover, preschool children at risk for dyslexia have poor PA skills and WM deficits in the comparison with children who do not have any problems in reading. Evidently, both PA and WM are important for developing reading skills. Current and past research has described which particular phonological skills make more significant impacts in the improvement of reading during the early learning years and has painted a complex portrait of readers' development. Individuals with reading difficulties perform lower than controls on the production of pronunciations for nonsense words (Gathercole \& Baddeley, 1993; Kyttala, Aunio, \& HautamaKi, 2010) and on word reading accuracy measures, confirming a deficit in the phonological processing system (e.g., Hansen \& Bowey, 1994). Taken together, these findings present both important theoretical and practical implications for future studies of the measurement and development of PA, WM, and dyslexia in preschool children across cultures.

\section{Acknowledgements}

The authors would like to thank all the people who helped in this study, including the pupils and staff of all the schools. Their time and assistance was invaluable to this study.

\section{References}

Abdelgawaad, H. E. (2005). Effect of the level of phonological awareness of word recognition for kindergarten and 2nd grade children (Unpublished doctoral dissertation). Elfayuom University, Elfayuom, Egypt.

Al Mannai, H., \& Everatt, J. (2005) Phonological processing skills as predictors of literacy amongst Arabic speaking Bahraini school children. Dyslexia, 11, 269-291. http://dx.doi.org/10.1002/dys.303

Alloway, T. P., \& Gathercole, S. E. (2006). Working memory and neurodevelopmental disorders. New York: Psychology Press.

Alloway, T. P., Gathercole, S. E., Adams. A., Willis, C., Eaglen, R., \& Lamont, E. (2005). Working memory and phonological awareness as predictors of progress towards early learning goals at school entry. British Journal of Developmental Psychology, 23, 417-426. http://dx.doi.org/10.1348/026151005X26804

Anthony, J., \& Francis, D. (2005). Development of phonological awareness. Current Directions in Psychological Science, 14(5), 255-259. http://dx.doi.org/10.1111/j.0963-7214.2005.00376.x

Ashour, A. (2011). The phonological awareness and its role in diagnosing and treating the children with dyslexia. Arabian Journal of Learning Disabilities, 1(1), 243-257. Retrieved from http://www.ldworldwide.org/research/-ajld

Baddeley, A. (1992). Working memory: The interface between memory and cognition. Journal of Cognitive Neuroscience, 4(3), 281-288. http://dx.doi.org/10.1162/jocn.1992.4.3.281

Baddeley, A. (1993). Short-term phonological memory and long-term learning: A single case study. European Journal of Cognitive Psychology, 5(2), 129-148. http://dx.doi.org/10.1080/09541449308520112 
Baddeley, A. (2003). Working memory: Looking back and looking forward. Nature Reviews Neuroscience, 4(10), 829-839. http://dx.doi.org/10.1038/nrn1201

Baddeley, A. D. (1986). Working memory. Oxford: Oxford University Press.

Baddeley, A. D. (2000). The episodic buffer: A new component of working memory? Trends in Cognitive Sciences, 4, 417-423. http://dx.doi.org/10.1016/S1364-6613(00)01538-2

Baddeley, A., Gathercole, S., \& Papagno, C. (1998). The phonological loop as a language learning device. Psychological Review, 105(1), 158-173. http://dx.doi.org/10.1037/0033-295X.105.1.158

Ball, E. W., \& Blachman, B. A. (1991). Does phoneme segmentation training in kindergarten make a difference in early word recognition and developmental spelling? Reading Research Quarterly, 24, 49-66. http://dx.doi.org/10.1598/RRQ.26.1.3

Beneventi, H., Tønnessen, F. E., Ersland, L., \& Hugdahl, K. (2010). Working memory deficit in dyslexia: Behavioral and FMRI evidence. International Journal of Neuroscience, 120(1), 9-51. http://dx.doi.org/10.3109/00207450903275129

Birch, S., \& Chase, C. (2004). Visual and language processing deficits in compensated and uncompensated college students with dyslexia. Journal of Learning Disabilities, 37, 389-410. http://dx.doi.org/10.1177/00222194040370050301

Bird, J., Bishop, D. V. M., \& Freeman, N. H. (1995). Phonological awareness and literacy development in children with expressive phonological impairments. Journal of Speech, Language and Hearing Research, 38(2), 446. Retrieved from http://jslhr.asha.org

Bishop, D. V. (2002). Dyslexia: Cause, correlate or consequence? Cortex, 38, 491-498. http://dx.doi.org/10.1016/S0010-9452(08)70018-2

Blachman, B. A., Schatschneider, C., Fletcher, J. M., Francis, D. J., Clonan, S. M., \& Shaywitz, B. (2004). Effects of intensive reading remediation for second and third graders and a 1-year follow-up. Journal of Educational Psychology, 96, 444-461. http://dx.doi.org/10.1037/0022-0663.96.3.444

Bowey, J. A. (2001). Nonword repetition and young children's receptive vocabulary: A longitudinal study. Applied Psycholinguistics, 22, 441-469. http://dx.doi.org/10.1017/S0142716401003083

Bradley, L. (1988). Rhyme recognition and reading and spelling in young children. In R. L. Masland \& M. W. Masland (Eds.), Preschool prevention of reading failure (pp. 143-162). Parkton, MD, US: York Press.

Bradley, L., \& Bryant, P. (1983). Categorizing sounds and learning to read: A causal connection. Nature, 301, 419-421. http://dx.doi.org/10.1038/301419a0

Bruck, M. (1992). Persistence of dyslexics' phonological awareness deficits. Developmental Psychology, 28, 874-886. http://dx.doi.org/10.1037/0012-1649.28.5.874

Bruck, M. (1993). Component spelling skills of college students with childhood diagnoses of dyslexia. Learning Disability Quarterly, 16, 171-184. http://dx.doi.org/10.2307/1511325

Bruck, M., \& Treiman, R. (1990). Phonological awareness and spelling in normal children and dyslexics: The case of initial consonant clusters. Journal of Experimental Child Psychology, 50, 156-178. http://dx.doi.org/10.1016/0022-0965(90)90037-9

Bruck, M., \& Treiman, R. (1990). Phonological awareness and spelling in normal children and dyslexics: The case of initial consonant clusters. Journal of Experimental Child Psychology, 50(1), 156-178. http://dx.doi.org/10.1016/0022-0965(90)90037-9

Brunswick, N., McCrory, E., Price, C. J., Frith, C. D., \& Frith, U. (1999). Explicit and implicit processing of words and pseudowords by adult developmental dyslexics: A search for Wernicke's Wortschatz? Brain, 122(10), 1901-1917. http://dx.doi.org/10.1093/brain/122.10.1901

Cabin, R. J., \& Mitchell, R. J. (2000). To Bonferroni or not to Bonferroni: when and how are the questions. Bulletin of the Ecological Society of America, 81(3), 246-248. Retrieved from http://www.jstor.org/stable/20168454

Carroll, J. M., \& Snowling, M. J. (2004). Language and phonological skills in children at high risk of reading difficulties. Journal of Child Psychology and Psychiatry, 45(3), 631-640. http://dx.doi.org/10.1111/j.1469-7610.2004.00252.x

Catts, H. W. (1989). Phonological processing deficits and reading disabilities. In A. Kamhi \& H. Catts (Eds.), Reading disabilities: A developmental language perspective (pp. 101-132). Boston: Allyn \& Bacon. 
de Bree, E. (2007). Dyslexia and phonology: A study of the phonological abilities of Dutch children at-risk of dyslexia. (Unpublished doctoral dissertation), Utrecht University, Utrecht, Netherlands.

de Jong, P. F. (1998). Working memory deficits of reading disabled children. Journal of Experimental Child Psychology, 70(2), 75-96. http://dx.doi.org/10.1006/jecp.1998.2451

Ehri, L. (1991). Development of the ability to read words. In R. Barr, M. L. Kamil, P. Mosenthal, \& P. D. Pearson (Eds.), Handbook of reading research (Vol. 2, pp. 383-417). New York: Longman.

Ehri, L. (1994). Development of the ability to read words: Update. In R. Ruddell, M. Ruddell, \& H. Singer (Eds.), Theoretical models and processes in reading (4th ed., pp. 323-358). Newark: DE: International Reading Association.

Ehri, L. C., Nunes, S. R., Willows, D. M., Schuster, B. V., Yaghoub-Zadeh, Z., \& Shanahan, T. (2001). Phonemic awareness instruction helps children learn to read: Evidence from the national reading panel's meta-analysis. Reading Research Quarterly, 36(3), 250-287. http://dx.doi.org/10.1598/RRQ.36.3.2

Eisenhart, C. (1947). The assumptions underlying the analysis of variance. Biometrics, 3, 1-21. http://dx.doi.org/10.2307/3001534

Elbeheri, G. (2004). Dyslexia in Egypt. In I. Smythe, J. Everatt \& R. Salter (Eds.), International book of dyslexia. Part 2: Countries (2nd ed, pp. 79-85). Chichester: Wiley \& Sons.

Elbeheri, G. (2007). Dyslexia: A guide for teacher and parent. Kuwait: Alqelam Publishers.

Elbeheri, G., Everatt, J., Reid, G., \& Al Mannai, H. (2006). Dyslexia assessment in Arabic. Journal of Research in Special Educational Needs, 3(6), 143-152. http://dx.doi.org/10.1111/j.1471-3802.2006.00072.x

Elmonayer, R. A. (2012). Promoting phonological awareness skills of Egyptian kindergarteners through dialogic reading. Early Child Development and Care, online first, 1-13. http://dx.doi.org/10.1080/03004430.2012.703183

Fawcett, A., \& Nicholson, R. (1995). Persistence of phonological awareness deficits in older children with dyslexia. Reading and Writing: An Interdisciplinary Journal, 7, 361-376. http://dx.doi.org/10.1007/BF01027724

Fletcher, J. M., Shaywitz, S. E., Shankweiler, D. P., Katz, L., Lieberman, I. Y., Stuebing, K. K., Francis, D. J., Fowler, A. E., \& Shaywitz, B. A. (1994). Cognitive profiles in reading disability: Comparisons of discrepancy and low achievement definitions. Journal of Educational Psychology, 86, 6-23. http://dx.doi.org/10.1037/0022-0663.86.1.6

Fox, B., \& Routh, D. K. (1980). Phonemic analysis and severe reading disability in children. Journal of Psycholinguistic Research, 9, 115-119. http://dx.doi.org/10.1007/BF01067466

Gathercole, S. E., \& Baddeley, A. D. (1993). Working memory and language. Hove: Lawrence Erlbaum Associates.

Gazzaniga, M. S., Ivry, R. B., \& Mangun, G. R. (2002). Cognitive neuroscience: The biology of the mind. New York: Norton.

Gilgil, N. M. (1995). Dyslexia: A diagnostic and remedial study. Cairo, Egypt: Maktabat Annahda Almasriyyah.

Gilgil, N. M., \& Agag, K. (2011). Manual of the Dyslexia Early Screening Test (2nd ed) [translated from English to Arabic]. Cairo, Egypt: Maktabat Annahda Almasriyyah.

Hansen, J., \& Bowey, J. A. (1994). Phonological analysis skills, verbal working memory, and reading ability in second-grade children. Child Development, 65(3), 938-950. http://dx.doi.org/10.2307/1131429

Hecht, S. A., Burgess, S. R., Torgesen, J. K., Wagner, R. K., \& Rashotte, C. A. (2000). Explaining social class differences in growth of reading skills from beginning kindergarten through fourth-grade: The role of phonological awareness, rate of access, and print knowledge. Reading and writing, 12(1), 99-128. http://dx.doi.org/10.1023/A:1008033824385

IBM Corp. Released. (2011). IBM SPSS Statistics for Windows, Version 20.0. Armonk, NY: IBM Corp.

Jeffries, S. A., \& Everatt, J. E. (2003). Differences between dyspraxics and dyslexics in sequence learning and working memory. Dyspraxia Foundation Professional Journal, 2, 12-21. Retrieved from http://www.dyspraxiafoundation.org.uk/professionals/rs_intro.php 
Jeffries, S., \& Everatt, J. (2004). Working memory: Its role in dyslexia and other specific learning difficulties. Dyslexia, 10(3), 196-214. http://dx.doi.org/10.1002/dys.278

Joanisse, M. F., Manis, F. R., Keating, P., \& Seidenberg, M. S. (2000). Language deficits in dyslexic children: Speech perception, phonology, and morphology. Journal of Experimental Child Psychology, 77(1), 30-60. http://dx.doi.org/10.1006/jecp.1999.2553

Jorm, A. F. (1983). Specific reading retardation and working memory: A review. British Journal of Psychology, 74, 311-342. http://dx.doi.org/10.1111/j.2044-8295.1983.tb01865.x

Kamhi, A. G., \& Catts, H. W. (1986). Toward an understanding of developmental language and reading disorders. Journal of Speech and Hearing Disorders, 51(4), 337. Retrieved from http://jshd.asha.org

Khalil, M., \& Dowah, A. (2007). Working memory disorders as a predictor of dyslexia level of primary school students. Egyptian journal of psychological studies, 49(15), 247-321.

Kirby, J., Parrila, R., \& Pfeiffer, S. (2003). Naming speed and phonological awareness as predictors of reading $\begin{array}{lllll}\text { development. Journal of } & \text { Educational }\end{array}$ http://dx.doi.org/10.1037/0022-0663.95.3.453

Kyttala, M., Aunio, P., \& HautamaKi, J. (2010). Working memory resources in young children with mathematical difficulties. Scandinavian Journal of Psychology, 51, 1-15. http://dx.doi.org/10.1111/j.1467-9450.2009.00736.x

Leather, C. V., \& Henry, L. A. (1994). Working memory span and phonological awareness tasks as predictors of early reading ability. Journal of Experimental Child Psychology, 58(1), 88-111. http://dx.doi.org/10.1006/jecp.1994.1027

Lindamood, P. C., Bell, N., \& Lindamood, P. (1992). Issues in phonological awareness assessment. Annals of Dyslexia, 42, 242-261. http://dx.doi.org/10.1007/BF02654948

Lovett, M. W., Steinbach, K. A., \& Frijters, J. C. (2000). Remediating the core deficits of developmental reading disability: A double-deficit perspective. Journal of Learning Disabilities, 33, 334-358. http://dx.doi.org/10.1177/002221940003300406

Lyon, G. R. (1995). Toward a definition of dyslexia. Annals of Dyslexia, 45, 3-30. http://dx.doi.org/10.1007/BF02648210

Manis, F. R., Doi, L. M., \& Bhadha, B. (2000). Naming speed, phonological awareness, and orthographic knowledge in second graders. Journal of Learning Disabilities, 33, 325-333. http://dx.doi.org/10.1177/002221940003300405

McDougall, S. J., \& Donohoe, R. (2002). Reading ability and memory span: Long-term memory contributions to span for good and poor readers. Reading and Writing, 15(3), 359-387. http://dx.doi.org/10.1023/A:1015224830778

McLoughlin, D., Leather, C., \& Stringer, P. (2002). The adult dyslexic: Interventions and outcomes. London: Whurr.

Miles, C. (1983). Effects of loud noise on sustained and selective attention (Unpublished doctoral dissertation). University of Wales, Cardiff, Wales.

Morais, J., Bertelsen, P., Cary, L., \& Alegria, J. (1987). Literacy training and speech segmentation. In P. Bertelsen (Ed.), The onset of literacy: Cognitive processes in reading.

Muter, V., \& Snowling, M. (1998). Concurrent and longitudinal predictors of reading: The role of metalinguistic and short-term memory skills. Reading Research Quarterly, 33, 320-337. http://dx.doi.org/10.1598/RRQ.33.3.4

Nation, K., Adams, J. W., Bowyer-Crane, C. A., \& Snowling, M. J. (1999). Working memory deficits in poor comprehenders reflect underlying language impairments. Journal of Experimental Child Psychology, 73(2), 139-158. http://dx.doi.org/10.1006/jecp.1999.2498

Nicolson, R. I., Fawcett, A. J., Moss, H., Nicolson, M. K., \& Reason, R. (1999). Early reading intervention can be effective and cost-effective. British Journal of Educational Psychology, 69, 47-62. http://dx.doi.org/10.1348/000709999157563

Nicolson, R., \& Fawcett, A. (2004). The dyslexia early screening test (2nd ed). London: Psychological Corporation. 
Nicolson, R., Fawcett, A., \& Baddeley, A. D. (1992). Working memory and dyslexia. London: Whurr.

Oakhill, J., \& Kyle, F. (2000). The relation between phonological awareness and working memory. Journal of Experimental Child Psychology, 75(2), 152-164. http://dx.doi.org/10.1006/jecp.1999.2529

Othman, R. (2009). Effectiveness of training program to improve phonological awareness for dyslexic kindergarten children (Unpublished master's thesis). Kafrelsheikh University, Kafrelsheikh, Egypt.

Palmer, S. (2000). Working memory: A developmental study of phonological recoding. Memory, 8(3), 179-193. http://dx.doi.org/10.1080/096582100387597

Pennington, B. F., Van Orden, G. C., Smith, S. D., Green, P. A., \& Haith, M. (1990). Phonological processing skills and deficits in adult dyslexics. Child Development, 61, 1753-1778. http://dx.doi.org/10.2307/1130836

Phillips, B. M., Clancy-Menchetti, J., \& Lonigan, C. J. (2008). Successful phonological awareness instruction with preschool children lessons from the classroom. Topics in Early Childhood Special Education, 28(1), 3-17. http://dx.doi.org/10.1177/0271121407313813

Pickering, S. J., \& Gathercole, S. E. (2001). Working memory test battery for children. London: Psychological Corporation.

Plaza, M., Cohen, H., \& Chevrie-Muller, C. (2002). Oral language deficits in dyslexic children: weaknesses in working memory and verbal planning. Brain and cognition, 48(2-3), 505-512.

Pneuman, S. (2009). Defining the early indicators of dyslexia: Providing the signposts to intervention (Doctoral dissertation, University of Bath). http://opus.bath.ac.uk/18539/1/Thesis_for_Susan_Pneuman.pdf

Rispens, J. E. (2004). Syntactic and phonological processing in developmental dyslexia (Doctoral dissertation). University Library Groningen, The Netherlands. Retrieved from dissertations.ub.rug.nl

Roodenrys, S., \& Stokes, J. (2001). Serial recall and nonword repetition in reading disabled children. Reading and Writing, 14(5), 379-394. http://dx.doi.org/10.1023/A:1011123406884

Rvachew, S., Ohberg, A., Grawburg, M., \& Heyding, J. (2003). Phonological awareness and phonemic perception in 4-year-old children with delayed expressive phonology skills. American Journal of Speech-Language Pathology, 12(4), 463. http://dx.doi.org/10.1044/1058-0360(2003/092)

Scheepers, M. (2009). Working memory: A comparison between dyslexic and non-dyslexic children. (Unpublished master's thesis). University of the Witwatersrand: Johannesburg, South Africa.

Seidenberg, M. S., \& McClelland, J. L. (1989). A distributed, developmental model of word recognition and naming. Psychological Review, 96(4), 523-568. http://dx.doi.org/10.1037/0033-295X.96.4.523

Share, D. L., \& Stanovich, K. E. (1995). Cognitive processes in early reading development: Accommodating individual differences into a model of acquisition. Issues in education: Contributions from educational psychology, 1(1), 1-57.

Share, D., Jorm, A., MacLean, R., \& Matthews, R. (1984). Sources of individual differences in reading $\begin{array}{lllll}\text { acquisition. Journal of Educational Psychology, } & 76, & 1309-1324 .\end{array}$ http://dx.doi.org/10.1037/0022-0663.76.6.1309

Smith-Spark, J. H., \& Fisk, J. E. (2007). Working memory functioning in developmental dyslexia. Memory, 15(1), 34-56. http://dx.doi.org/10.1080/09658210601043384

Smith-Spark, J., Fisk, J., Fawcett, A., \& Nicolson, R. (2003). Investigating the central executive in adult dyslexics: Evidence from phonological and visuospatial working memory performance. European Journal of Cognitive Psychology, 15(4), 567-587. http://dx.doi.org/10.1080/09541440340000024

Snow, C. E., Burns, M. S., \& Griffin, P. (1999). Language and literacy environments in preschools. Champaign, IL: ERIC Clearinghouse on Elementary and Early Childhood Education, University of Illinois.

Snow, C., Burns, M., \& Griffin, P. (Eds.). (1998). Preventing reading difficulties in young children. Washington, DC: National Academy Press.

Snowling, M. J. (1981). Phonemic deficits in developmental dyslexia. Psychological Research, 43(2), 219-234. http://dx.doi.org/10.1007/BF00309831

Snowling, M. J. (2001). From language to reading to dyslexia. Dyslexia, 7(1), 37-46. http://dx.doi.org/10.1002/dys.185 
Snowling, M. J. (2008). Specific disorders and broader phenotypes: The case of dyslexia, Quarterly Journal of Experimental Psychology, 61(1), 142-156. http://dx.doi.org/10.1080/17470210701508830

Snowling, M. J., Chiat, S., \& Hulme, C. (1991). Words, nonwords, and phonological processes: Some comments on Gathercole, Wilis, Emslie, and Baddeley. Applied Psycholinguistics, 12, 369-373. http://dx.doi.org/10.1017/S0142716400009279

Stackhouse, J., Wells, B., Pascoe, M., \& Rees, R. (2002). From phonological therapy to phonological awareness. Seminars in Speech and Language, 23(1), 23-34. http://dx.doi.org/10.1055/s-2002-23509

Stanovich, K. E. (1994). Romance and reality. The Reading Teacher, 47, 280-291.

Stanovich, K. E., Siegel, L. S., \& Gottardo, A. (1997). Converging evidence for phonological and surface subtypes of reading disability. Journal of Educational Psychology, 89(1), 114. http://dx.doi.org/10.1037/0022-0663.89.1.114

Storch, S. A., \& Whitehurst, G. J. (2002). Oral language and code-related precursors to reading: evidence from a $\begin{array}{lllll}\text { longitudinal structural model. Developmental psychology, } & 38(6), & 934 .\end{array}$ http://dx.doi.org/10.1037/0012-1649.38.6.934

Swan, D., \& Goswami, U. (1997). Phonological awareness deficits in developmental dyslexia and the phonological representations hypothesis. Journal of Experimental Child Psychology, 66(1), 18-41. http://dx.doi.org/10.1006/jecp.1997.2375

Swanson, H. L. (1994). Short-Term Memory and Working Memory Do Both Contribute to Our Understanding of Academic Achievement in Children and Adults with Learning Disabilities? Journal of Learning Disabilities, 27(1), 34-50. http://dx.doi.org/10.1177/002221949402700107

Swanson, H. L. (2003). Age-related differences in learning disabled and skilled readers' working memory. Journal of Experimental Child Psychology; Journal of Experimental Child Psychology, 85(1), 1-31. http://dx.doi.org/10.1016/S0022-0965(03)00043-2

Swanson, H. L., \& Ashbaker, M. H. (2000). Working memory, short-term memory, speech rate, word recognition and reading comprehension in learning disabled readers: Does the executive system have a role? Intelligence, 28(1), 1-30. http://dx.doi.org/10.1016/S0160-2896(99)00025-2

Swanson, H. L., Ashbaker, M. H., \& Lee, C. (1996). Learning-disabled readers' working memory as a function of processing demands. Journal of Experimental Child Psychology, 61(3), 242-275. http://dx.doi.org/10.1006/jecp.1996.0016

Trehearne, M., P. (2003). Comprehensive literacy resource for kindergarten teachers. Retrieved from http://www.hand2mind.com

Vellutino, F. R. (1979). Dyslexia: Theory and research. Cambridge, MA: MIT Press.

Wagner, R. K., \& Torgesen, J. K. (1987). The nature of phonological processing and its causal role in the acquisition of reading skills. Psychological Bulletin, 101, 192-212. http://dx.doi.org/10.1037/0033-2909.101.2.192

Wagner, R. K., Torgesen, J. K., Rashotte, C. A., Hecht, S. A., Barker, T. A., Burgess, S. R. et al. (1997). Changing relations between phonological processing abilities and word-level reading as children develop from beginning to skilled readers: A 5-year longitudinal study. Developmental Psychology, 33, 468-479. http://dx.doi.org/10.1037/0012-1649.33.3.468

Wechsler, D. (1997). Wechsler Memory Scale (3rd ed). San Antonio: The Psychological Corporation.

Wilson, A. M., \& Lesaux, N. K. (2001). Persistence of phonological processing deficits in college students with dyslexia who have age-appropriate reading skills. Journal of Learning Disabilities, 34, 394-400. http://dx.doi.org/10.1177/002221940103400501

Zayed, A. M. (2011). Effectiveness of working memory training program for improvement of some cognitive variables of dyslexic pupils in First stage of Basic Education (Unpublished doctoral dissertation). Kafrelsheikh University, Kafrelsheikh, Egypt. 